\title{
The Effects of Internet Usage and GDP on Electricity Consumption: The Case of Turkey
}

\author{
M. Veysel KAYA* Bayram Veli DOYAR ${ }^{* *}$
}

Fatih DEMIR $^{* * *}$

\begin{abstract}
This paper aims to reveal the connection between electricity use growth, GDP growth and the growth in the number of internet users for Turkey with the time series data covering 1994-2014. Since internet usage is one of the quickest ways of accessing information, its effects on electricity consumption has great importance in respect to economic growth. In line with this purpose, we implement ARDL bounds test for cointegration and find long-run relationship between the variables. Then, we estimate the long-run and the short-run coefficients from the selected ARDL model. Accordingly, growth in the number of internet users and GDP growth have positive and statistically significant effects on electricity use growth in Turkey both in the short-run and the long-run. Also, the coefficient of lagged error correction term is found negative, which validates the long-run relationship. Since the coefficient, however, found between -1 and -2 , it is concluded that the longrun equilibrium is achieved in a decreasing fluctuating form. Consequently, we recommend energy conversation policies for Turkey.
\end{abstract}

Key Words: Internet usage, electricity consumption, GDP, Turkey, ARDL.

JEL Classification: Q43, C22.

\section{İnternet Kullanımı ve GSYH'nın Elektrik Tüketimi Üzerindeki Etkileri: Türkiye Örneği}

$\ddot{O} Z$

Bu çalışma Türkiye için 1994-2014 dönemi ylllık zaman serisi verilerini kullanarak elektrik tüketimi, GSYH ve internet kullanımı arasındaki ilişkileri göstermeyi amaçlamaktadır. Internet kullanımı bilgiye erişimde en hızl yollardan biri olduğu için, elektrik tüketimine etkisi de ekonomik büyüme açısından büyük öneme sahiptir. Bu amaç yönelik olarak ARDL sinır testi uygulanmış ve değişkenler arasında eşbütünleşme ilişkisi tespit edilmiştir. Ardından seçilen ARDL modelinden kisa ve uzun dönem katsaylları tahmin edilmiştir. Sonuçlar hem uzun hem de kısa dönemde Türkiye'de internet kullanımı ve GSYH'nin elektrik tüketimi üzerinde pozitif ve istatistiksel olarak anlamlı etkilerinin olduğunu göstermiştir. Ayrıca gecikmeli hata düzeltme katsayısı, uzun dönem ilişkisini onaylayacak şekilde negatif işaretli olarak bulunmuştur. Ancak, bu katsayı -1 ile -2 arasında yer aldığından uzun dönem dengesinin dalgalanarak azalan bir biçimde sağlandiğı sonucuna varılmıştır. Sonuç olarak Türkiye için enerji koruma politikaları önerilmiştir.

Anahtar Kelimeler: İnternet kullanımı, elektrik tüketimi, GSYH, Türkiye, ARDL.

JEL Sinıflandirmasi: $Q 43, C 22$.

\section{INTRODUCTION}

Energy use and economic growth relationship has been extensively studied by numerous authors. With the increasing usage of information and communication

\footnotetext{
* Associate Professor, Kirikkale University, Department of Economics, (mveyselkaya@ yahoo.com)

** PhD Student, Kirikkale University, Economics, (bvdoyar@gmail.com)

${ }^{* * * *}$ Research Assistant, Kirikkale University, Department of Econometrics, (fatihdemir@kku.edu.tr)
} 
technologies (ICT's) as a result of information age, this relationship has been started to be examined by various aspects. One of the analyzed relationships is between electricity consumption and internet usage. When we take into consider the great rise in internet usage in Turkey during the recent years, this subject becomes significant.

Many of previous studies largely focus on GDP and electricity consumption for various countries. Therefore, we can say that electricity use and ICT field is new. Also, we find no studies examining the linkage amongst internet usage and electricity consumption for Turkey.

The main question we seek to answer is "how does growth in the number of internet users affect the growth in electricity use?". Therefore, the target of this paper is to examine the impacts of internet use on electricity consumption in Turkey. Thus, our hypothesis of "higher growth in the number of internet users leads to higher electricity use growth" will be tested.

We use annual percentage changes in electricity consumption, GDP and internet users number data spanning the period 1994-2014. To see the connection between the variables we utilized ARDL estimation. After revealing that the variables share cointegrating relationship, we estimate long-run and short-run coefficients.

The rest of the article is organized as follows: second section gives statistical information about internet and electricity energy in Turkey, third section summarizes the empirical literature, fourth section explains the data set, model and methodology, fifth section displays empirical outcomes, and the final section is conclusions.

\section{A STATISTICAL REVIEW ON INTERNET AND}

\section{ELECTRICITY USAGE IN TURKEY}

\section{A. Internet Usage}

In this subsection, we summarize the internet usage structure of Turkey by presenting statistical data between 2004-2015 period. All of the following figures (Figures 1-4) in this subsection are prepared by the author using the data obtained from the web site of Turkish Statistical Institute (Turkstat) ${ }^{1}$.

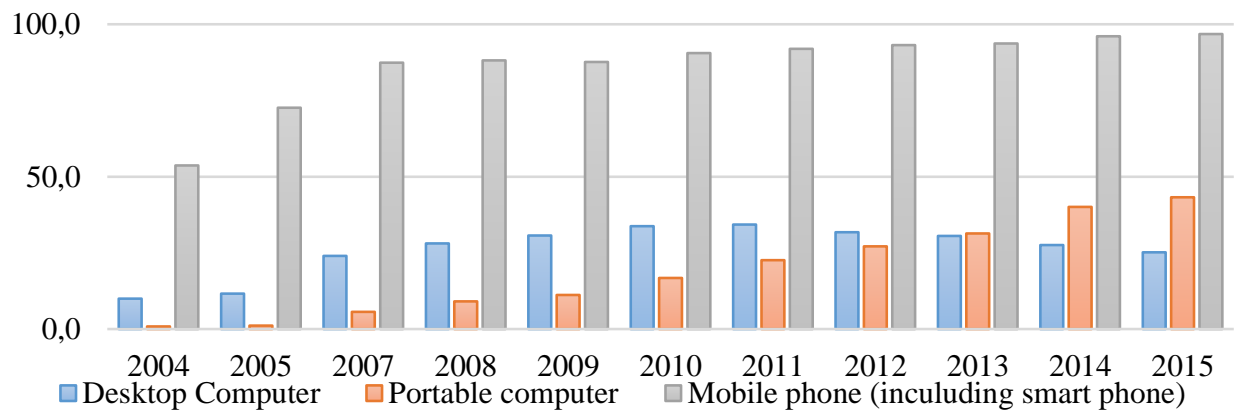

Figure 1. Availability of devices in households. (Source: TurkStat).

\footnotetext{
1 "Portable computer (Laptop, Tablet PC)" and "portable computer (Laptop, netbook, tablet)" data were combined and presented together in the title of "portable computer" by the author.
} 
In Figure 1, the availabilities of some of technological devices which can provide internet access in households are shown. Until 2013, total population has more desktop computer than the portable ones. With 2013, portable computer availability exceeds desktop computer availability. It is observed that the mobile phone availability has been higher than any other devices in considered years. In 2015, when $96.8 \%$ of total population has mobile phone, $25.2 \%$ and $43.2 \%$ of total population has desktop computer and portable computer, respectively.

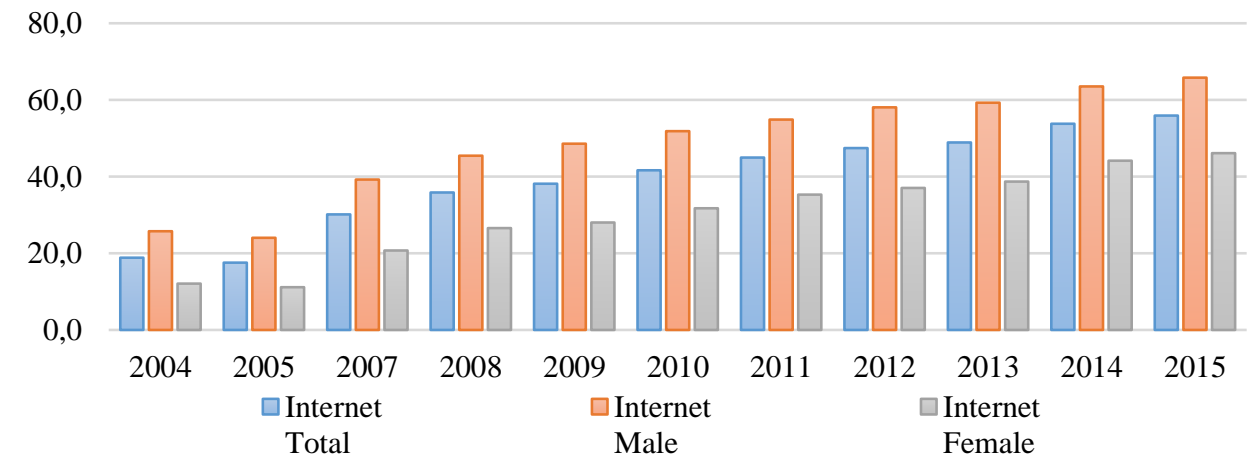

Figure 2. Internet users by sex. (Source: TurkStat).

It can be said that there is a huge difference in internet usage statistics between the considered time interval in Turkey. As presented on Figure 2, internet usage has been more common for male population than females since 2004. Female internet users comprise $46.1 \%$ of female population for 2015 . When only $18.8 \%$ of total population is internet user in 2004, it is raised to $55.9 \%$ in 2015.

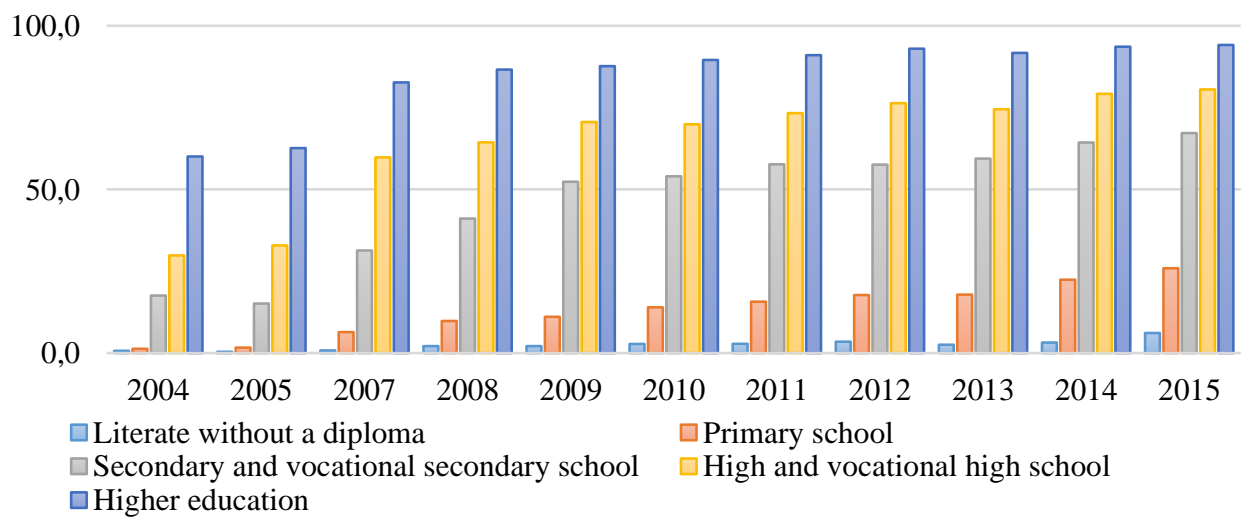

Figure 3. Internet users by education. (Source: TurkStat).

Internet usage statistics by education can be seen on Figure 3. It is observed that as education increases, then internet usage ratio increases. Accordingly, people who literate without a diploma are the least internet users when the ones with higher education are the most internet users. Over the years, ratio of higher educated 
population in internet usage is increased as well as others. The ratio of higher educated ones is $94.1 \%$ for 2015 .

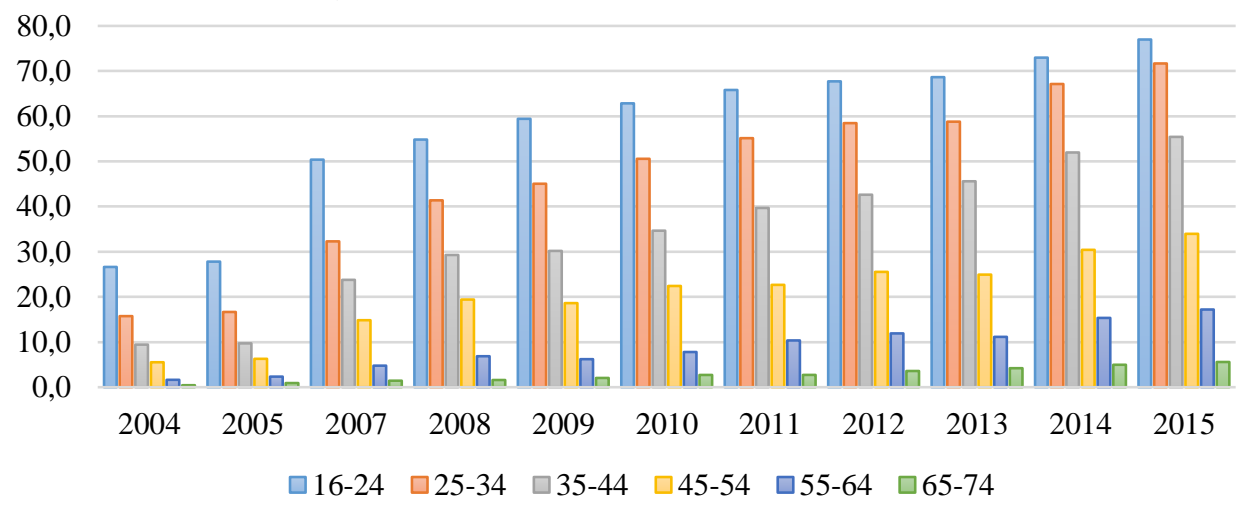

Figure 4. Internet users by age groups. (Source: TurkStat).

Internet users by age groups presented in Figure 4. Internet usage has been more common for lower age group. When internet usage in 16-24 age group is $26.6 \%$ in 2004, it is increased to $77 \%$ in 2015. Similar situation in education is also observed for age groups. Accordingly, elderly people are less internet users. Internet usage in 65-74 age group is $5.6 \%$ in 2015 .

\section{B. Electricity Generation and Consumption}

This subsection summarizes electricity generation and consumption of Turkey between 1970-2013 period. All data obtained from TurkStat and all of following figures (Figures 5-6) are prepared by the author using the data.

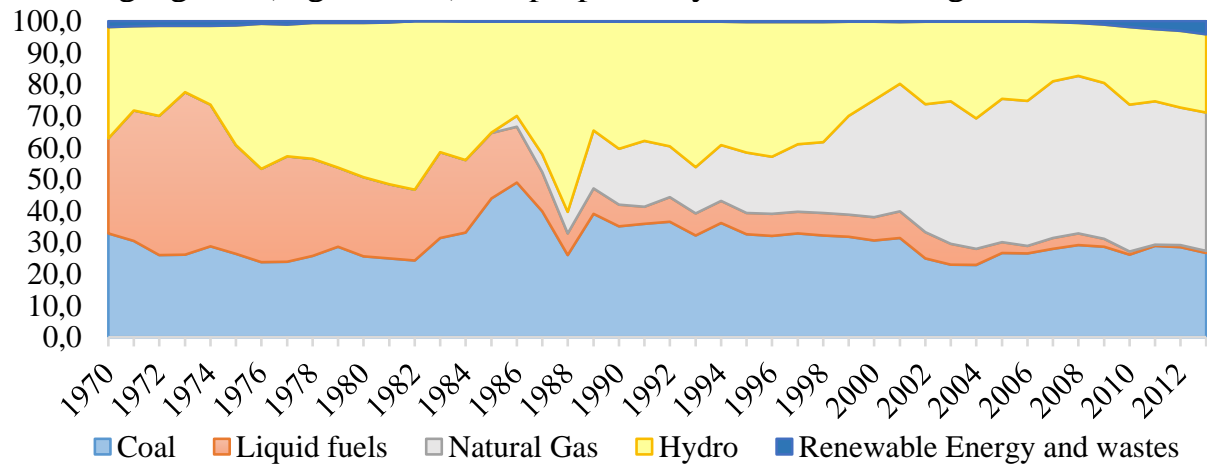

Figure 5. Electricity generation shares by energy resources.

(Source: TurkStat).

Figure 5 shows electricity generation shares by sources. As represented with yellow area, from mid-1970's to the end of 1999, electricity generation resource was mostly hydro. The highest share of this resource in electricity generation is $60.3 \%$ which was reached in 1988. It is also seen that sometimes the share of coal, which is represented by the light blue area, is more than the share of hydro. Usage of natural gas with the purpose of electricity generation starts in 1985 . 
As seen on grey area, with 2000, natural gas exceeds hydro in terms of share. Today, natural gas still has the highest share in generating electricity. This share is $43.8 \%$ in 2013. Renewable energy and wastes has the lowest portion for given time period. It, however, starts to increase in late 2000's. As for liquid fuels, whose share exhibits a decreasing trend, have $0.7 \%$ portion in total generation in 2013 .

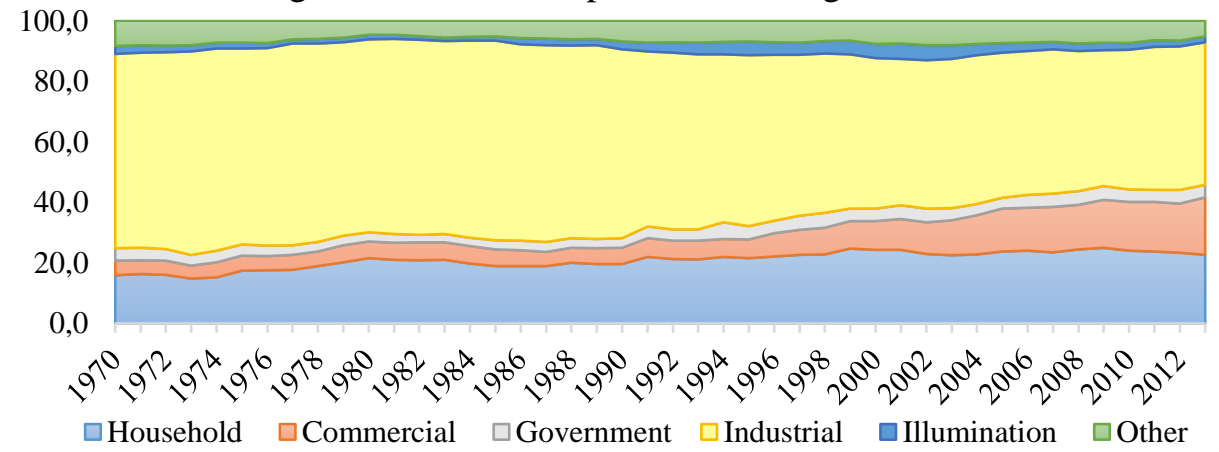

Figure 6. Distribution of net electricity consumption by sectors.

(Source: TurkStat).

Figure 6 demonstrates net electricity consumption by sectors. According to the figure, industry, which is represented by the yellow area, is the leading sector in net electricity consumption in the interval. But the diminishing trend of the sector is remarkable. It's share decreases from about $60-65 \%$ in between of 1970-1990 to $47.1 \%$ in 2013. Household sector that represented with light blue area has the second highest share between the years presented with $20.9 \%$ mean. The share of the sector is $22.7 \%$ in 2013 . The increasing trend of the orange area, which stands for commercial sector, from about $4.5 \%$ in 1970's to about $17 \%$ in 2010 's is also should be indicated.

\section{LITERATURE REVIEW}

It's generally known that the energy use and economic growth relationship literature starts with Kraft and Kraft (1978) who find a causal relationship from GNP to energy use for the USA. But, energy consumption and information technology literature may be started with Thirring (1958), as Sadorsky (2012) states.

The literature on the relationship of electiricty consumption and ICT's is considerably limited. We can summarize this literature as follows:

Salahuddin and Alam (2015) use annual time series data to estimate the effects of economic growth and internet usage on electricity consumption for Australia in 1985-2012. Using bounds test, they find internet usage and economic growth have positive and significant impacts on electricity use. Estimated long-run coefficients from ARDL approach show that internet usage and economic growth increase electricity consumption. Also, the robustness of these long-run coefficients are confirmed by DOLS estimates. Finally, Granger causality test results show a one-way causality running from internet usage to electricity use. 
Sadorsky (2012) examines ICT and electricity use relationship for 19 emerging countries using GMM. ICT variables used in the work are internet users, mobile cellular subscriptions and personal computers. He develops four models: The base model includes none of ICT variables while each of others include an ICT variable. The long-run coefficients of ICT variables are found smaller than income coefficients.

Ishida (2015) explores ICT investment, GDP and energy relationships using ARDL approach for Japan for the years 1980-2010. He sets up two models namely production and energy demand functions. For the production model, labor, energy consumption and capital coefficients are found positive and statistically significant in the long-run. But, coefficient of ICT is found insignificant in the short and the long-run. For the energy demand model, coefficients of price and energy consumption are significant in the long-run and their signs conform to theory. In the short-run, coefficient of ICT is significant. Consequently, he decides ICT investments moderately decreases energy use.

When we look at the relationship of GDP and electricity consumption, we find broader literature compared to the relationship of electricity consumption and ICT's. Most of them focus on casual relationship between the variables considered. Some of recent studies on this literature can be found as follows:

Dogan (2015) analyses relationships between economic growth and electricity use both from renewables and non-renewables for Turkey in 1990-2012. Implementing bounds, Johansen and Gregory-Hansen tests, he reveals that the variables have not long-run relationship. VECM-based Granger causality test shows that in the short-run electricity use from renewables and economic growth, and electricity use from non-renewables and economic growth are neutral each other. In the long-run, there is one causality runs from electricity use form renewables, electricity use from non-renewables, capital and labor to economic growth and also, from economic growth, electricity consumption from renewables, capital and labor to electricity consumption from non-renewables.

Bayar and Ozel (2014) use yearly data of electric power use and GDP growth for emerging countries between 1991-2011 to see long-run and causalities between them. They apply Pedroni, Johansen Fisher and Kao cointegration tests and find the long-run association. According to FMOLS and DOLS results for the panel reveal that the income elasticities of electricity consumption are 0.33 and 0.32, respectively. For Turkey, these elasticities are found 0.39 for FMOLS and 0.37 for DOLS. Finally, panel Granger causality test outcomes uncover tow-way causality between economic growth and electricity use.

Aslan (2014) uses ARDL approach with yearly electricity use and GDP per head data covering 1968-2008 for Turkey. ARDL bounds test results indicate that there is a cointegrating assosication between elecrtricity use and GDP per capita, and vice versa. Long-run coefficients of ARDL model are found 1.012 and 1.047, respectively. These results mean that electricity use (GDP per head) boosts GDP per head (electricity use) in Turkey. According to Granger test results, while there is no causality evidence between the variables in the short-run, bidirectional 
causality is found between them. He also states that while the speed of adjustment is $3.9 \%$ each year when electricity consumption is dependent variable, $3.2 \%$ each year when GDP per capita is dependent variable.

Acaravci and Ozturk (2012) search causality between per head electricity use and GDP per head for Turkey using the data that also includes employment ratio covering 1968-2006 period. ARDL bounds test outcomes point to long-run connection between the variables. They also find that income elasticities of electricity consumption which are estimated from the ARDL model are positive in the long and the short runs. Accordingly, when a $1 \%$ increase in electricity use brings a $0.87 \%$ rise in GDP in the short-run, this rise for electricity use in the longrun is found $0.32 \%$ for Turkey. Lastly, short-run, long-run and strong Granger causality models uncover that there is not causality between GDP per head and per head electricity use.

Narayan, Narayan and Popp (2010) investigate causal connections between GDP and electricity use with 1980-2006 data for seven panels namely Western Europe, Asia, Africa, Latin America, Middle East, G6, and worldwide. Applying Pedroni's residual based cointegration test they find the variables are panel cointegrated for all panels. The result for Middle East is found statistically insignificant. For G6, causality sign has found negative. For the rest, there is a longrun positive Granger causality from electricity use to GDP. Alternatively, they find causality from GDP to electricity consumption for all panels.

Narayan \& Smyth (2009) investigate causality between electricity use, exports and GDP data covering 1974-2002 for Middle Eastern countries. Using Westerlund cointegration test they discover that the variables share long-run relationship. According to panel Granger causality test results there is a Granger causality from GDP to exports and from electricity use to GDP. In the long-run, causality runs from exports and electricity use to GDP and from exports and GDP to electricity use. Finally, they use FMOLS estimator to get long-run elasticities and find that if electricity use increases $1 \%$, then GDP increases $0.04 \%$; if exports increase $1 \%$, then GDP increases $0.17 \%$; and if GDP increases $1 \%$, then electricity use increases $0.95 \%$.

There are also detailed reviews on electricity consumption and GDP nexus e.g. (Payne, 2010) and (Ozturk, 2010). These resources can be utilized by researchers for further information.

\section{DATA, MODEL AND METHODOLOGY}

\section{A. Data}

Our dataset consists of electrical energy consumption (gigawatt-hour, per capita) which is obtained from Eurostat Database, GDP (per capita) and the number of internet users (per capita) which are attained from World Development Indicators (WDI) Databank. Each variable is used in their annual percentage change forms to find out the elasticities. Hereafter, ELC, GDP and INT represent annual percentage changes in electricity consumption, GDP and the number of internet users, respectively. 


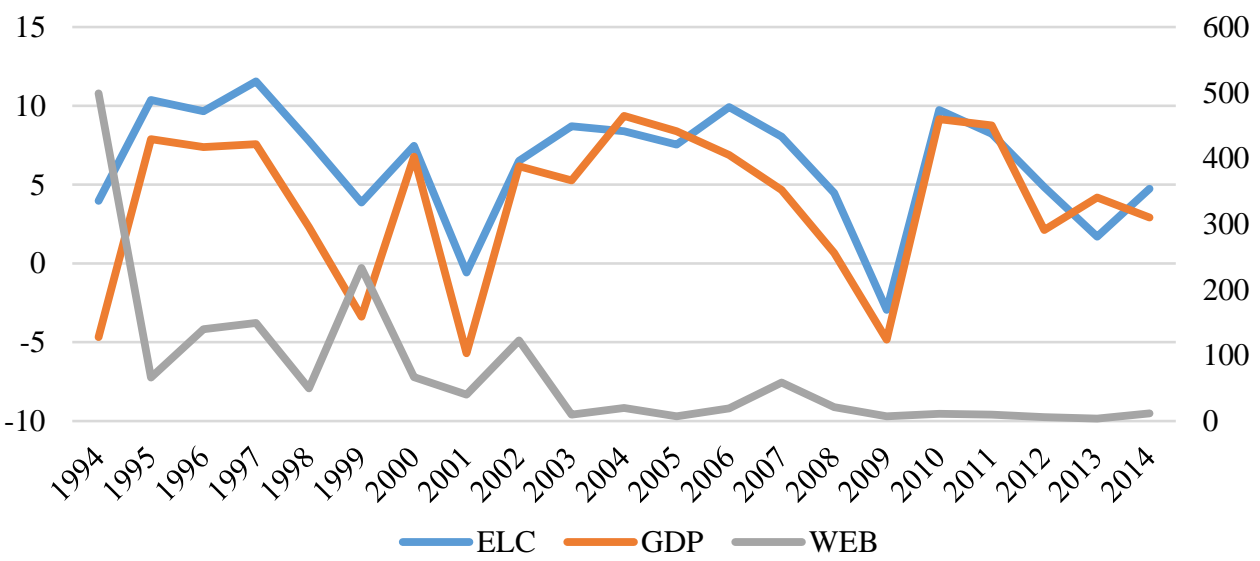

Figure 7. Growths in electricity consumption, GDP and internet users.

The time path of the variables that are used in the analysis are shown on Figure 7 as a line chart. For electricity and GDP growth, left axis of the figure should be followed. For growth in the number of internet users, right axis of the figure should be considered. The blue line represents electricity consumption growth. It decreases only in 2001 and 2009, which are economic crisis years. The orange line stands for GDP growth. Accordingly, it decreases in economic crisis years, 1994, 2001 and 2009. Decrease in 1999 corresponds to earthquake period in Turkey. The grey line shows percentage change in internet usage. The grey line displays internet usage growth in Turkey between 1993-2013. Internet usage in Turkey increased about $500 \%$ in 1994 . In the following years, there is no decrease observed.

\section{B. Model}

Following Sadorsky (2012), and Salahuddin and Alam (2015), who use electricity consumption as a function of economic growth and internet usage, we can write the following model:

$$
E L C=f(G D P, W E B)
$$

We can write this model as an open function as:

$$
E L C_{t}=\alpha_{0}+\alpha_{1} G D P_{t}+\alpha_{2} W E B_{t}+u_{t}
$$

where $\mathrm{u}$ is stochastic error term and subscript $t$ stands for time. Since we work with percentage data, there is no need to take natural logarithms of the variables.

\section{Methodology}

First of all, we utilize Augmented Dickey-Fuller (ADF) (Dickey and Fuller, 1981) and Phillips-Perron (PP) (Phillips and Perron, 1988) tests to check that the series are not I(2). This check is necessary before to run ARDL bounds test.

Pesaran, Shin and Smith (2001) have developed a cointegration approach which is based on $F$-statistics. They generated two sets of critical values. If the calculated $F$-statistics is greater than the upper limit of the critical value, the null hypothesis of no cointegration is rejected. If the calculated $F$-statistics is smaller 
than the lower limit of the critical value, the null hypothesis of cointegration cannot be rejected. There is no conclusion if the calculated $F$-statistics takes part between the bounds. Bounds testing have some superiorities in comparison to other cointegration tests. Ozturk and Acaravci (2013) state these superiorities as follows: (i) it's not compulsory that all the variables share same stationarity level, (ii) it is effective for small samples, (iii) variables can have dissimilar lags, and (iv) it uses a single reduced form equation. We apply ARDL bounds testing approach to see whether the variables have cointegrating association or not. Since we work with a small sample, there couldn't be a better option than ARDL procedure. ARDL model related to equation (2) can be written as:

$$
\begin{aligned}
\Delta E L C=\beta_{0}+ & \sum_{i=1}^{n} \beta_{1 i} \Delta E L C_{t-i}+\sum_{i=0}^{n} \beta_{2 i} \Delta G D P_{t-i}+\sum_{i=0}^{n} \beta_{3 i} \Delta W E B_{t-i} \\
& +\gamma_{1} E L C_{t-1}+\gamma_{2} G D P_{t-1}+\gamma_{3} W E B_{t-1} \\
& +\varepsilon_{t}
\end{aligned}
$$

For optimal lag length selection, we utilized Akaike information criterion (AIC). For our ARDL model, the null hypothesis of no cointegration is $H_{0}=\gamma_{1}=$ $\gamma_{2}=\gamma_{3}=0$, whereas alternative of cointegration is $H_{0} \neq \gamma_{1} \neq \gamma_{2} \neq \gamma_{3} \neq 0$.

\section{EMPIRICAL RESULTS}

Table 2 shows the outcomes obtained from ADF and PP tests. ADF test shows that variables ELC, GDP and WEB are level stationary in 5\%, 1\% and $10 \%$ significance levels, respectively. According to PP test, all variables are level

\begin{tabular}{|c|c|c|}
\hline & $\mathrm{ADF}$ & PP \\
\hline & Level & Level \\
\hline$E L C$ & $-3.798 * *$ & $-3.817 * * *$ \\
\hline$G D P$ & $-4.879 * * *$ & $-4.879 * * *$ \\
\hline$W E B$ & $-2.772 *$ & $-6.628 * * *$ \\
\hline
\end{tabular}
stationary in $1 \%$ level.

Table 2: Unit root tests.

Since our observation number is 21 , maximum lag for ARDL is limited to 2 lags. Based on AIC, proper model is found as ARDL $(1,1,1)$. Table 3 reveals the outcomes from bounds test for cointegration. Since the calculated $F$-statistics is higher than the upper critical value at $1 \%$ level, we decide that there is a long-run association between the variables. 
Table 3: Bounds test for cointegration.

\begin{tabular}{llll}
\hline$F$-Statistics & $k$ & $99 \%$ Lower bound & $99 \%$ Upper bound \\
\hline 10.387 & 2 & 5.15 & 6.36 \\
\hline
\end{tabular}

Long-run coefficients that estimated from ARDL $(1,1,1)$ model are shown on Table 4. It's seen that all variables are statistically significant at $1 \%$ significance level excluding constant term which is significant at 5\% level. The outcomes reveal that the higher growths on number of internet users and GDP mean that higher growth in electricity consumption. If $G D P$ and $W E B$ increase $1 \%$, then $E L C$ increases by $0.85 \%$ and $0.02 \%$, respectively.

Table 4: Long-run coefficients from ARDL $(1,1,1)$.

\begin{tabular}{cccc}
\hline Variable & Coefficient & Std. Error & t-Statistic [Prob.] \\
\hline Dependent Variable: ELC & & & \\
GDP & $0.851^{* * *}$ & 0.092 & $9.221[0.000]$ \\
C & $0.023^{* * *}$ & 0.004 & $4.792[0.000]$ \\
$1.472 * *$ & 0.601 & $2.446[0.028]$ \\
\hline
\end{tabular}

Superscripts $* *$ and $* * *$ show $5 \%$ and $1 \%$ significance levels. Optimal lag order is selected based on AIC.

Table 5 shows error-correction depiction of ARDL $(1,1,1)$ model. Each variable is found significant at $1 \%$ level. The coefficients show that explanatory variables have positive effects on ELC. Accordingly, if GDP and WEB increase $1 \%$, then $E L C$ increases $0.69 \%$ and $0.02 \%$, respectively. The coefficient of lagged error-correction term $E C T(-1)$ is found negative which is expected. So, the longrun association is validated. The value of $E C T(-1)$ coefficient is found -1.25 and statistically significant at $1 \%$ level. Narayan and Smyth (2006) state that if ECT (1) coefficient is found between -1 and -2 , then the long-run equilibrium is achieved in a decreasing fluctuating form. Therefore, we can say that the correction will occur in a decreasing fluctuating form, since our coefficient is also between the stated intervals.

Table 5: Error-correction model based on ARDL $(1,1,1)$.

\begin{tabular}{cccc}
\hline Variable & Coefficient & Std. Error & t-Statistic [Prob.] \\
\hline Dependent Variable: $\Delta(E L C)$ & & & \\
$\Delta(G D P)$ & $0.692^{* * *}$ & 0.079 & $8.757[0.000]$ \\
$\Delta(W E B)$ & $0.019^{* * *}$ & 0.006 & $2.972[0.010]$ \\
$E C T(-1)$ & $-1.250^{* * *}$ & 0.235 & $-5.313[0.000]$ \\
\hline
\end{tabular}

Superscripts $* *$ and $* * *$ show $5 \%$ and $1 \%$ significance levels. Optimal lag order is selected based on AIC.

Results from diagnostic tests presented on Table 6. We use BreuschGodfrey LM test for serial correlation, White test for heteroskedasticity, Ramsey's RESET test for functional form and Jarque-Bera test for normality. Accordingly, 
we have normally distributed, homoskedastic and not serially correlated error terms. Also, our model specification is true.

Table 6: Diagnostic tests.

\begin{tabular}{ll}
\hline Test & Value [Prob.] \\
\hline Serial correlation $\left(\chi^{2}\right)$ & $0.216[0.897]$ \\
Heteroskedasticity $\left(\chi^{2}\right)$ & $3.507[0.622]$ \\
Normality $\left(\chi^{2}\right)$ & $0.222[0.894]$ \\
Functional form $(F)$ & $2.034[0.177]$ \\
$R^{2} 0.878$ & Adj. $R^{2} 0.834$ \\
\hline
\end{tabular}

For the stability of coefficients, cumulative sum (CUSUM) and cumulative sum of squares (CUSUMQ) stability tests were implemented. As is seen from Figure 8, the parameters are stable at 5\% significance level.

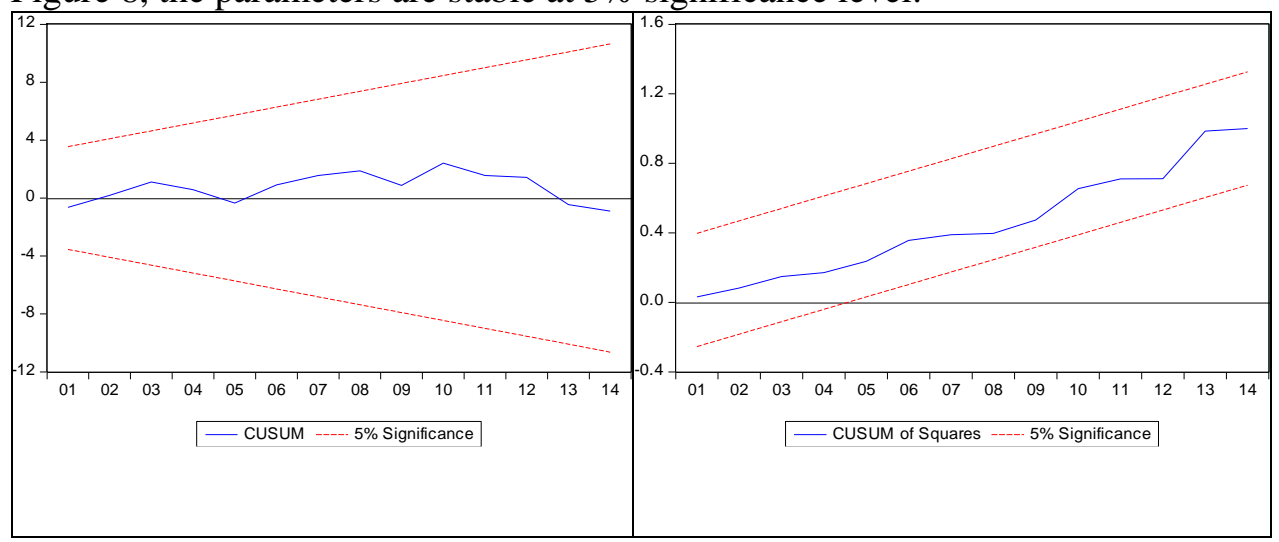

Figure 8. Plots of CUSUM and CUSUMQ tests.

\section{CONCLUSION AND POLICY SUGGESTIONS}

The objective of current paper is to investigate the link between the growth in the number of internet users and electricity use growth for Turkey employing the data covering 1994-2014. Since we work with a small sample, we prefer to utilize ARDL model.

After finding the series are not I(2), we execute ARDL bounds test for cointegration and detect a long-run link between the variables. Both of estimated long-run and short-run coefficients of GDP growth and internet usage growth have positive and statistically significant effect on electricity consumption growth. In addition, we find a $1 \%$ rise in internet usage growth boosts electricity consumption growth by $0.02 \%$ in the short-run. Also, a $1 \%$ rise in GDP growth means $0.69 \%$ in electricity use growth. The coefficient of lagged error-correction term is found 1.25 , which validates the cointegrating relationship. This coefficient lets us to say that the correction will occur in a diminishing fluctuating form. Estimated long-run coefficients are found higher than the short-run coefficients. Accordingly, a $1 \%$ 
increase in GDP growth and internet usage growth mean $0.85 \%$ and $0.02 \%$ increase in electricity consumption growth, respectively. These findings confirm our hypothesis of "higher internet usage means higher electricity consumption". Our results are compatible with the outcomes of Sadorsky (2012) and Salahuddin and Alam (2015).

Economic growth, of course, is a goal that every country wants to achieve. Internet, on the other hand, is one of the necessary tools that can serve to economic growth through access to information. Since the increases in GDP and internet usage boosts electricity consumption, it requires a stable energy policy by increasing electircal efficiency. Especially when we think that the required electricity is mostly produced with imported natural gas, the country becomes indirectly foreign-dependent on electricity. In addition, coal, which is the second important source of electricity generation in the country, has negative effects on the environment. In this regard, electricity should be generated by domestic and environmentally friendly or less harmful sources.

\section{REFERENCES}

Acaravci, A., \& Ozturk, I. (2012). Electricity Consumption and Economic Growth Nexus: A Multivariate Analysis for Turkey. Amfiteatru Economic, 14 (31), 246-257. https://core.ac.uk/download/files/153/6652894.pdf

Aslan, A. (2014). Causality Between Electricity Consumption and Economic Growth in Turkey: An ARDL Bounds Testing Approach. Energy Sources, Part B: Economics, Planning, and Policy, 9(1), 25-31. DOİ:10.1080/15567241003681882

Bayar, Y., \& Ozel, H. A. (2014). Electricity Consumption and Economic Growth in Emerging Economies. Journal of Knowledge Management, Economics and Information Technology, $I V(2), \quad 1-18 . \quad$ http://www.scientificpapers.org/wp-content/files/1453_YilmazElectricity_Consumption_and_Economic_Growth_in_Emerging_Economies.pdf

Dickey, D. A., \& Fuller, W. A. (1981). Likelihood ratio statistics for autoregressive time series with a unit root. Econometrica, 49(4), 1057-1072. DOI: 10.2307/1912517

Dogan, E. (2015). The relationship between economic growth and electricity consumption from renewable and non-renewable sources: A study of Turkey. Renewable and Sustainable Energy Reviews, 52, 534-546. DOİ:10.1016/j.rser.2015.07.130

European Commission Eurostat Database. Accessed on the 19th of March, 2016. http://ec.europa.eu/eurostat/data/database

Ishida, H. (2015). The effect of ICT development on economic growth and energy consumption in Japan. Telematics and Informatics, 32, 79-88. DOI:10.1016/j.tele.2014.04.003

Kraft, J., \& Kraft, A. (1978). Relationship between energy and GNP. Journal of Energy Finance and Development, 3, 401-403.

Narayan, P. K., \& Smyth, R. (2006). What determines migration flows from low-income to high income countries? An empirical investigation of Fiji-U.S. migration 1971-2001. Contemporary Economic Policy, 24(2), 332-342. http://papers.ssrn.com/sol3/papers.cfm?abstract_id=904956

Narayan, P. K., \& Smyth, R. (2009). Multivariate granger causality between electricity consumption, exports and GDP: Evidence from a panel of Middle Eastern countries. Energy Policy, 37(1), 229-236. DOI:10.1016/j.enpol.2008.08.020

Narayan, P. K., Narayan, S., \& Popp, S. (2010). Does electricity consumption panel Granger cause GDP? A new global evidence. 87(10), 3294-3298. DOİ:10.1016/j.apenergy.2010.03.021

Ozturk, I. (2010). A literature survey on energy-growth nexus. Energy Policy, 38, 340-349. DOİ:10.1016/j.enpol.2009.09.024 
Ozturk, I., \& Acaravci, A. (2013). The long-run and causal analysis of energy, growth, openness and financial development on carbon emissions in Turkey. Energy Economics, 36, 262-267. DOİ:10.1016/j.eneco.2012.08.025

Payne, J. E. (2010). A survey of the electricity consumption-growth literature. Applied Energy, 87, 723-731. DOİ:10.1016/j.apenergy.2009.06.034

Pesaran, M. H., Shin, Y., \& Smith, R. J. (2001). Bounds testing approaches to the analysis of level relationships. Journal of Applied Econometrics, 16(3), 289-326. DOI: 10.1002/jae.616

Phillips, P. C., \& Perron, P. (1988). Testing for a unit root in time series regression. Biometrika, 75(2), 335-346. DOİ: 10.1093/biomet/75.2.335

Sadorsky, P. (2012). Information communication technology and electricity consumption in emerging economies. Energy Policy, 48, 130-136. DOİ:10.1016/j.enpol.2012.04.064

Salahuddin, M., \& Alam, K. (2015). Internet usage, electricity consumption and economic growth in Australia: A time series evidence. Telematics and Informatics, 862-878. DOİ:10.1016/j.tele.2015.04.011

Thirring, H. (1958). Energy for Man: Windmills to Nuclear Power. Indiana: Indiana University Press. Turkish Statistical Intitute. Accessed on the 30th of January, 2016. http://www.tuik.gov.tr

World Bank World Development Indicators. Accessed on 19th of March, 2016. http://data.worldbank.org/data-catalog/world-development-indicators

\section{SUMMARY}

There is an expanding literature on electricity use and economic growth relationship in various aspects by various authors. But, we can say that the papers on the linkage between ICT and electricity use are relatively less. Therefore, we add internet usage in the existing function. In this way, we investigate the link between growths in electricity use, the number of internet users and GDP for Turkey when electricity use is dependent variable and test the hypothesis of "higher internet usage growth means higher electricity use growth".

Substantial rises in the usage of information and comminution technologies (ICT's) were observed in Turkey over the past two decades. As one of the ICT's, the number of internet users, showed serious increases especially in the 1990's. It's seen that higher educated people have higher internet usage ratio in Turkey. Also, internet usage is more common in male population than in female ones. As for age, internet users are mostly in 16-24 age group. On the other hand, electricity generation is provided largely by natural gas and the highest electricity consuming sector is industry in Turkey.

The dataset used in this paper covers the period from 1994 to 2014. Each variable is used its annual percentage change form. In the first phase, we test the series for unit roots. Outcomes of Augmented Dickey-Fuller (ADF) and PhillipsPerron (PP) tests reveal that all variables are stationary in their levels. After finding that the variables are stationary, we apply Autoregressive Distributed Lag (ARDL) bounds test to unveil probable long-run relationship. According to cointegration test results, the variables share long-run relationship. Since the long-run association is established, the long-run and the short-run coefficients are estimated from proper ARDL model on the next step. All variables are found statistically significant. In the short-run $1 \%$ increase in GDP growth means $0.7 \%$ increase in electricity use growth, when $1 \%$ rise in growth in the number of internet users boosts electricity use growth by $0.02 \%$. The coefficient of lagged error correction term is found -1.25 
which means equilibrium is ensured in fluctuating form. The long-run coefficients are also found highly similar to the short-run coefficients. Hereunder, when GDP growth and the growth in the number of internet users increase 1\%, then electricity use growth increases by $0.85 \%$ and $0.023 \%$, respectively. In the last phase, we confirm that our outcomes pass serial correlation, heteroskedasticity, normality, functional form and stability diagnostics tests.

The positive relationship between GDP growth and electricity use growth brings the importance of electrical energy as an input to light. The positive relationship is also observed between electricity use growth and GDP growth. This outcome verifies our hypothesis of "higher internet usage growth means higher electricity use growth". Our results are consistent with some of previous studies.

When we take into consideration all of these outcomes, we recommend electricity generation with nature friendly resources. Since more electrical energy is needed to provide economic growth and internet access is the fastest information retrieval way in these days we are going through, our policy implication gains meaning. 